\title{
Review and Classification of Knowledge in Engineering Design
}

\author{
Cristina Carro Saavedra ${ }^{1}$, Teresa Serrano Villodres ${ }^{1}$, and Udo Lindemann ${ }^{1}$ \\ ${ }^{1}$ Technical University of Munich, Institute of Product Development, Garching, Germany \\ carrosaavedra@pe.mw.tum.de
}

\begin{abstract}
Understanding what types of knowledge need to be managed is essential for researchers and practitioners in order to implement knowledge management within the engineering design process. However, obtaining a fast overview from literature of the types of knowledge to consider is not an easy task. In order to identify the types of knowledge in engineering design, we conducted a literature review searching for classifications of design knowledge. We analysed the types of knowledge from the literature and summarized them in a taxonomy to classify design knowledge. The taxonomy can be used as a theoretical base for researchers and practitioners dealing with knowledge management in engineering design, in order to support the understanding of the type of knowledge to consider for their purposes. It can be also used to classify the knowledge of a company in order to match it with the situations during the design process that each of the identified knowledge types can support.
\end{abstract}

Keywords: knowledge $\cdot$ knowledge types $\cdot$ literature review

\section{Introduction}

Design knowledge is defined by [1] as "knowledge that can be used to produce designs". Different types of design knowledge are needed for product design. Knowledge management is the discipline that aims at capturing, distributing and effectively using knowledge in organizations [2]. The main purpose of managing knowledge is not to become more knowledgeable, but to increase the awareness of possible solutions to problems that already exist and how to access those [3]. Knowledge management in engineering design is beneficial because it avoids "reinventing the wheel" and repeating past mistakes [4].

Understanding what types of knowledge need to be managed is essential for researchers and practitioners in order to implement knowledge management within the engineering design process. However, obtaining a fast overview from literature of the existing knowledge types is not an easy task. Some authors such as [5] classify design knowledge in market, human, procedural and technology knowledge. Others, classify knowledge in engineering design as technical know-how, functional and structural rules, technological laws and socio-technical understanding [6]. There are numerous classifications but they are partially redundant (what is the difference between 
procedural knowledge and technical know-how?). Each author provides a different classification and it is difficult to get an overview of the types of knowledge involved in the design process. Furthermore, the types of knowledge provided in the literature are usually very general. What is included in technical know-how? Could technical know-how be further specified in e.g. product know-how, design process know-how and manufacturing process know-how? Could product know-how, design process know-how and manufacturing process know-how be also further specified?

In order to get an overview of the types of knowledge in engineering design, we conducted a literature review searching for classifications of design knowledge. We analysed the classifications to identify what were the similarities and differences between those and we came up with a taxonomy to classify design knowledge in dimensions with their corresponding characteristics.

The paper is structured as follows: section 2 exposes the definitions of key terms for our work; section 3 describes the procedure for our literature review; section 4 presents the results; section 5 states the conclusions; and further work is described in section 6 .

\section{Definition of Main Terms}

Three terms appear constantly in knowledge management literature and should therefore be defined. Those terms are data, information and knowledge, as well as the relations between them. [7] defines data as "unorganized and unprocessed facts". Information is for them "the aggregation of processed data which makes decision making easier". They define knowledge as "evaluated and organized information that can be used purposefully in a problem solving process". Numerous authors provide similar definitions, whereas some others do not even agree that knowledge can be codified. These authors claim that knowledge exists only in the mind of people and not in any form of written document. For them, all that is written is information [8].

On the other hand, there are also numerous authors that do not try to strictly separate the terms and they treat them indistinctly. [9] defines knowledge management as the discipline that "promotes an integrated approach to identify, capture, evaluate, retrieve, and share all of an enterprise's information assets. These assets may include databases, documents, policies, procedures, and previously un-captured expertise and experience in individual workers". [9] establishes in this definition no difference between knowledge, information or even data. For our literature research, we also consider knowledge and information indistinctly, as many authors did not expose the definitions of the terms they used in their publications.

\section{$3 \quad$ Procedure for the Literature Review}

We reviewed over 800 publications searching for classifications of design knowledge. Since our purpose was summarizing the variety of types of knowledge that have been already identified, we did not look into documents containing knowledge itself (like patents or design reports) but we looked into scientific publications that try to classify and work with those types of knowledge. The publications were extracted from Google Scholar, Scopus, Web of Science and the library of the Technical University of Munich 
(TUM) between October 2015 and April 2016. Table 1 depicts the searches. All the selected publications cannot be referenced in this paper due to place constraints, but we show the number of publications to give the reader an idea of the research extension.

Table 1. Overview of the searches made for the literature review.

\begin{tabular}{|c|c|c|c|c|c|}
\hline Search words & Source & Sorted by & $\begin{array}{l}\text { Number of } \\
\text { results }\end{array}$ & $\begin{array}{l}\text { Re- } \\
\text { viewed }\end{array}$ & Selected \\
\hline Knowledge management & $\begin{array}{l}\text { Google } \\
\text { Scholar }\end{array}$ & Relevance & 3960000 & 100 & 8 \\
\hline $\begin{array}{l}\text { Types of knowledge in } \\
\text { engineering design }\end{array}$ & $\begin{array}{l}\text { Google } \\
\text { Scholar }\end{array}$ & Relevance & 3210000 & 200 & 7 \\
\hline $\begin{array}{l}\text { Types of knowledge depending } \\
\text { on the owner of the knowledge }\end{array}$ & $\begin{array}{l}\text { Google } \\
\text { Scholar }\end{array}$ & Relevance & 269000 & 60 & 3 \\
\hline $\begin{array}{l}\text { Product knowledge in design } \\
\text { engineering }\end{array}$ & Scopus & Relevance & 6335 & 20 & 2 \\
\hline $\begin{array}{l}\text { What are the product knowledge } \\
\text { necessary in design phase of a } \\
\text { product }\end{array}$ & $\begin{array}{l}\text { Google } \\
\text { Scholar }\end{array}$ & Relevance & 2540000 & 30 & 2 \\
\hline $\begin{array}{l}\text { Tacit and explicit knowledge in } \\
\text { design processes }\end{array}$ & $\begin{array}{l}\text { Google } \\
\text { Scholar }\end{array}$ & Relevance & 186000 & 30 & 1 \\
\hline $\begin{array}{l}\text { Design engineers and technical } \\
\text { professionals at work }\end{array}$ & $\begin{array}{l}\text { Google } \\
\text { Scholar }\end{array}$ & Relevance & 1 & 1 & 1 \\
\hline $\begin{array}{l}\text { Knowledge in engineering } \\
\text { design }\end{array}$ & Scopus & Relevance & 30372 & 103 & 4 \\
\hline $\begin{array}{l}\text { Customer knowledge in product } \\
\text { engineering }\end{array}$ & $\begin{array}{l}\text { Google } \\
\text { Scholar }\end{array}$ & Relevance & 983000 & 30 & 1 \\
\hline $\begin{array}{l}\text { Reuse knowledge in product } \\
\text { engineering }\end{array}$ & $\begin{array}{l}\text { Google } \\
\text { Scholar }\end{array}$ & Relevance & 474000 & 50 & 2 \\
\hline $\begin{array}{l}\text { Internal and external knowledge } \\
\text { in engineering design }\end{array}$ & $\begin{array}{l}\text { Google } \\
\text { Scholar }\end{array}$ & Relevance & 1090000 & 10 & 1 \\
\hline $\begin{array}{l}\text { Reuse knowledge in engineering } \\
\text { design }\end{array}$ & $\begin{array}{l}\text { Google } \\
\text { Scholar }\end{array}$ & Relevance & 30372 & 200 & 11 \\
\hline $\begin{array}{l}\text { What knowledge is needed to } \\
\text { design a product }\end{array}$ & Scopus & Relevance & 945 & 50 & 4 \\
\hline $\begin{array}{l}\text { Organization information of } \\
\text { product engineering }\end{array}$ & $\begin{array}{l}\text { Google } \\
\text { Scholar }\end{array}$ & Relevance & 1290000 & 80 & 5 \\
\hline $\begin{array}{l}\text { Innovative knowledge of } \\
\text { product engineering }\end{array}$ & $\begin{array}{l}\text { Google } \\
\text { Scholar }\end{array}$ & Relevance & 1220000 & 20 & 1 \\
\hline Knowledge in product design & $\begin{array}{l}\text { Web of } \\
\text { Science }\end{array}$ & Relevance & 4360000 & 100 & 6 \\
\hline $\begin{array}{l}\text { Knowledge identification in } \\
\text { design engineering }\end{array}$ & $\begin{array}{l}\text { Google } \\
\text { Scholar }\end{array}$ & Relevance & 2610000 & 90 & 2 \\
\hline $\begin{array}{l}\text { Experience knowledge in } \\
\text { engineering design }\end{array}$ & Scopus & Relevance & 4752 & 15 & 2 \\
\hline $\begin{array}{l}\text { Search for specific titles or } \\
\text { books }\end{array}$ & TUM & - & - & - & 32 \\
\hline
\end{tabular}


From the reviewed publications, we selected 95 that explicitly named types of design knowledge. We discarded the sources that did not clearly define which types of knowledge they considered for the work.

\section{$4 \quad$ Literature Review}

\subsection{Results}

We have classified the selected publications according to the product they develop (i.e. type of industry). We decided to do that because the type of industry was usually well defined in the publication and we were interested to see if there were differences between the types of design knowledge that different industries consider. Some of the types of knowledge named in the reviewed publications are presented in Table 2.

Table 2. Examples of the types of knowledge found in the literature for each type of industry.

\begin{tabular}{|c|c|c|}
\hline Type of industry & Type of knowledge & Author \\
\hline \multirow[t]{7}{*}{ Product not specified } & Learning by doing & {$[10]$} \\
\hline & Competitor knowledge & {$[10]$} \\
\hline & Human knowledge & [11], [5] \\
\hline & Codified knowledge & {$[12]$} \\
\hline & Tacit knowledge & {$[12]$} \\
\hline & Process knowledge & {$[13]$} \\
\hline & Object knowledge & [1] \\
\hline \multirow[t]{7}{*}{ Electromechanical } & Knowledge contacts & {$[14]$} \\
\hline & Interactions, trade-offs and design rules & {$[14]$} \\
\hline & Explicit knowledge & {$[15,16]$} \\
\hline & Design process knowledge & {$[15]$} \\
\hline & Typical values & {$[16]$} \\
\hline & Experiential knowledge & {$[17]$} \\
\hline & Tacit knowledge & {$[17]$} \\
\hline \multirow[t]{8}{*}{ Structure engineering } & Internal knowledge & {$[18]$} \\
\hline & Social knowledge networks & {$[18]$} \\
\hline & Engineering actors & [19] \\
\hline & Fundamental design concepts & [19] \\
\hline & Customer knowledge & {$[20]$} \\
\hline & Internal sources of knowledge & {$[21]$} \\
\hline & External sources of knowledge & {$[21]$} \\
\hline & External knowledge & {$[22]$} \\
\hline
\end{tabular}




\begin{tabular}{lll}
\hline Mechanical products & Knowledge process & {$[22]$} \\
& Personal knowledge & {$[23]$} \\
& Process knowledge & {$[24]$} \\
Competitor knowledge & {$[24]$} \\
Realization knowledge & {$[25]$} \\
Declarative knowledge & {$[25]$} \\
Explicit knowledge & {$[26]$} \\
Implicit knowledge & {$[26]$} \\
Tacit knowledge & {$[26]$} \\
& Fundamental design concepts & {$[27]$} \\
Criteria and specifications & {$[27]$} \\
& Practical considerations & {$[27]$} \\
Technology knowledge & {$[28]$}
\end{tabular}

In total we obtained 48 types of knowledge from publications that did not specify the product they referred to, 30 types of knowledge from the field of electromechanical product development, 10 types from structure engineering, 15 types of knowledge from mechanical product development and 10 types of knowledge from publications dealing with other products (chemicals, plastics, etc.).

We did not identify any remarkable difference between the types of knowledge named in each type of industry. The types of knowledge were mostly described in a generic way that could be applicable to all groups. Types like internal/external knowledge, tacit/explicit knowledge were found in all types of industry. Types of knowledge more specific to engineering design like design process knowledge or fundamental design concepts were also expressed in those terms, applicable to all types of industries. For this reason, we did not further consider the separation depending on the product to be developed.

\subsection{Summary}

Analysing the types of knowledge compiled, we realized that some ways of classifying knowledge in literature were not mutually exclusive but they complement each other, i.e. the same knowledge can be classified at the same time in more than one way (e.g. knowledge can be simultaneously explicit and external). However, there are also mutually exclusive ways of classifying knowledge (e.g. knowledge cannot be at the same time explicit and tacit). Given these possibilities of combination, we summarized the results of the literature review in a taxonomy (Fig. 1). A taxonomy is defined as an "ordered arrangement of groups and categories" [29]. We considered five groups that we named "dimensions" and that are complementary, i.e. any piece of knowledge can always be classified in all dimensions. For each dimension, knowledge can be classified in one category of the dimension. The categories are mutually exclusive, i.e. in each 
dimension knowledge can only belong to one category. Thus, the way of reading the taxonomy is like a morphological box, well known in product development [30].

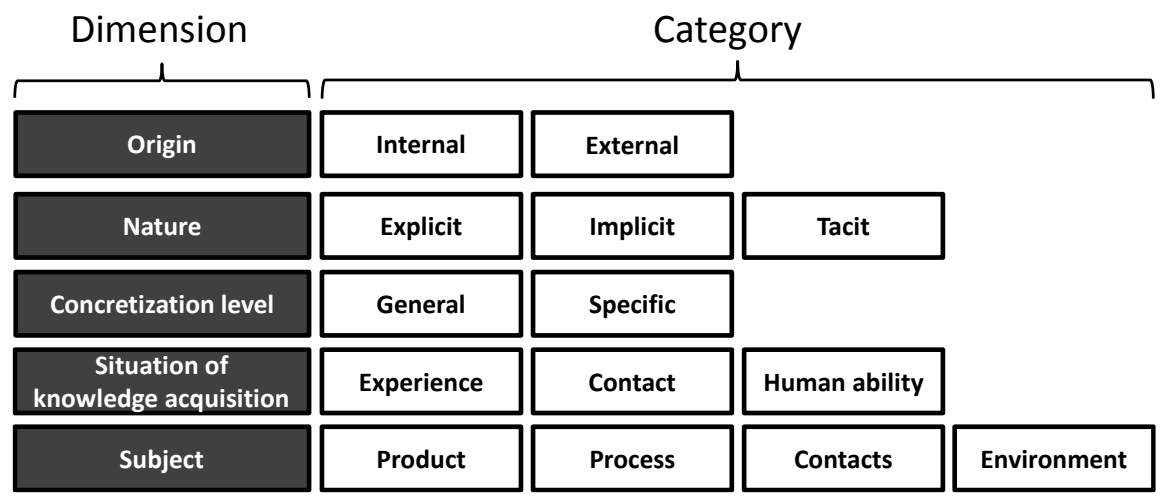

Fig. 1. Taxonomy of types of knowledge in engineering design.

To come up with the taxonomy, we first grouped all types of knowledge that were similar, paying special attention to those types that meant the same but were named differently. Table 3 shows how we proceeded to determine the dimension "concretization level". An example of how we clustered is the case of basic, principal, general, elementary, generic and fundamental knowledge. We grouped these types of knowledge together because we considered that the authors that named those categories referred to the same type of knowledge. The second step was to assign names to the clusters. In this case, we assigned the name "general knowledge". Finally, we proposed the dimensions that embrace the categories established. Thus, in this case, we realized that "general knowledge" and "specific knowledge" are mutually exclusive and we assigned them to the dimension that we named as "concretization level". We proceeded in this way to determine all dimensions and categories. The complete results cannot be exposed due to place constraints. Table 3 serves as an example to show the procedure.

Table 3. Categories of the dimension "concretization level".

\begin{tabular}{lll}
\hline Category & Type of knowledge named in literature & Author \\
\hline General knowledge & & \\
& Basic knowledge & {$[14]$} \\
& General design knowledge & {$[1],[31]$} \\
& General process knowledge & {$[32]$} \\
& Principle knowledge & {$[33]$} \\
& Elementary knowledge & {$[34]$} \\
& Fundamental design concepts & {$[27]$} \\
& Generic knowledge & {$[22]$} \\
& Specialist knowledge & {$[14]$} \\
Specific knowledge & & \\
& Specific knowledge & {$[1],[22],[34]$} \\
& Domain-specific basic knowledge & {$[32]$} \\
& Product specific parameters & {$[14]$} \\
\hline
\end{tabular}


The dimension "origin" defines where the knowledge comes from in the company. It can be categorized as internal to the company, like project reports or new ideas from R\&D departments; or external to the company, like knowledge obtained from research articles or customers.

The dimension "nature" defines the essence of the knowledge. Explicit knowledge is documented whereas tacit knowledge is not articulable and it exists only in people's mind. Implicit knowledge is knowledge that has not been articulated and thus it is still in people's mind but it could be possible to articulate it.

The dimension "concretization level" defines how specific is the knowledge. General knowledge is independent of the domain, i.e. it does not belong to a specific business. Specific knowledge is particular to an industry or a product.

The dimension "situation of knowledge acquisition" describes in which activity was the knowledge gained. Knowledge can be the result of experience, it can be transferred from a contact (either person or document) or it can be inherit to the abilities of a person.

The dimension "subject" defines to which entity the knowledge is referring to. In the case of engineering design, four subjects were identified: knowledge can be about the product to be designed, about the process (either the design process and its activities or the manufacturing process of the product), about contacts, i.e. stakeholders related in some way to the product, and about the operational environment of the product. Further specifications of the categories of the dimension subject are presented in Table 4 . The procedure to determine the subcategories was the same as the procedure followed to establish the other dimensions and categories.

Table 4. Categories and subcategories of the dimension "subject".

\begin{tabular}{lll}
\hline Category & Subcategory & Sub-subcategory \\
\hline Product & Constraints and specifications & \\
& Conceptual & \\
& Structural & \\
& Functional & \\
& Behavioral & \\
& Technical & \\
& Calculations & Installation requirements \\
Process & Manufacturing process & Realization \\
& & Practical considerations \\
& & Technology \\
& & Realization \\
& Design process & Practical considerations \\
Contacts & Supplier & \\
& Customer & \\
& Competitor & \\
Environment & Other stakeholders & \\
& Legislation & \\
& Country/market & \\
& Environmental entity & \\
\hline
\end{tabular}




\section{Conclusions}

This paper presents a review of the types of knowledge considered in engineering design literature. The following conclusions can be extracted:

- The terms information and knowledge are often used indistinctly in literature.

- The types of knowledge named in the literature are abstract and generalizable.

- Some types of knowledge are complementary, i.e. a piece of knowledge can be categorized within both types at the same time.

- Many types of knowledge are named differently in the literature but they can be considered synonyms.

- The dimension "subject" is more named and specified in literature than the other dimensions.

The results are summarized in a taxonomy that represents an overview of the types of knowledge found in the literature. The types of knowledge in the taxonomy are not redundant and they are specified as much as possible for the field of engineering design. We could not point out differences in the types of knowledge for the different industries because the specific knowledge for each industry was not named in the literature.

The dimension "subject" is the only one that could be subdivided, because for this dimension the number of sub-classifications in literature was remarkably higher than for the other dimensions. This seems to indicate that this dimension is more relevant to be considered for engineering design than the others.

The taxonomy enables the classification of knowledge from different perspectives. For example, an employee of company A classifies as "internal knowledge" the knowledge available in company $\mathrm{A}$, whereas an employee of company B classifies the same knowledge as "external knowledge". The type of knowledge depends on the point of view of the classifier.

The paper at hand contributes to the research community providing a summary of a large amount of hardly comparable literature findings aligned in one unique publication. The taxonomy provides a theoretical base for researchers and practitioners dealing with knowledge management in engineering design, in order to select the right way of classifying knowledge for their purposes. Another use of the taxonomy is to classify the knowledge of a company in order to match it with the situations during the design process that each knowledge type can support. Design situations, characterized by their i.e. design phase, available time or personality of the designers could be matched with the most appropriate knowledge type to support them.

One limitation of the taxonomy is the subjectivity in the analysis of the literature findings. We had to interpret the meaning of the knowledge types in order to cluster the types of knowledge to create the taxonomy. Besides, the completeness of the taxonomy is limited to the reviewed literature and therefore, types of knowledge may be missing. For example, for the dimension "process" only "design" and "manufacturing" were explicitly named, but there are other processes involved in the life of a product. If the other processes can be included in a sub-category of "design process" or if they should be added as new categories of the dimension "process" must be clarified. 


\section{$6 \quad$ Further Work}

The taxonomy should be validated with industry experts with two main objectives: 1) check understanding by practitioners; 2) identify new dimensions or categories that may not have been addressed in the reviewed publications.

It will be also investigated which ways of classifying knowledge are appropriate for which purposes of knowledge management. For example, classifying knowledge according to its origin can serve as the basis to define a strategy for open innovation, while classifying knowledge according to its situation of knowledge acquisition can serve to establish training or mentoring programs for knowledge development.

Ways of automatically matching the knowledge types with the design situations will be explored considering machine learning tools like Bayesian networks or artificial neural networks. The classification of knowledge in a taxonomy may be too restrictive to depict the numerous relations between the types of knowledge. In this case, it will be considered pushing the taxonomy towards an ontology.

\section{References}

1. Van Aken, J. E.: Valid knowledge for the professional design of large and complex design processes. Design Studies 26 (4), pp. 379-404 (2005)

2. Davenport, T. H.: Saving IT's Soul: Human-Centered Information Management. Harvard business review 72 (2), pp. 119-131 (1994)

3. Ling, T. N., Yih, G. C., Eze, U. C., Gan G. G. G.: Knowledge Management drivers for organisational competitive advantage. Proceedings of Applied International Business Conference (2008)

4. Koenig, M. E. D.: Why KM - the importance of knowledge management, www.kmworld.com (visited on 01/01/2016) (2012)

5. Yuan Fu, Q., Ping Chui, Y., Helander, M. G.: Knowledge identification and management in product design. In Journal of Knowledge management 10 (6), pp. 50-63 (2006)

6. Ropohl, G.: Knowledge types in technology. International Journal of technology and design education 7 (1-2), pp. 65-72 (1997)

7. Ameri, F., Dutta, D.: Product lifecycle management: closing the knowledge loops. Computer-Aided Design and Applications 2 (5), pp. 577-590 (2005)

8. Churchman, C. W.: The Design of Inquiring Systems: Basic Concepts of Systems and Organizations. Bencis Books, New York (1971)

9. Duhon, B.: It's all in our heads. Inform 12 (8), pp. 8-13 (1998)

10. Malerba, F.: Learning by firms and incremental technical change. The economic journal, pp. 845-859 (1992)

11.Tama, I. P., Reidsema, C.: Product knowledge identification and modelling for virtual collaboration environment. Technology Management for Global Economic Growth (PICMET), 2010 Proceedings of PICMET'10: IEEE (2010)

12.Dietz, P., Ort, A., Penschke, S.: Classification of product knowledge-an approach to optimal feedback strategies for design. Globalization of Manufacturing in the Digital Communications Era of the 21st Century: Springer, pp. 783-799 (1998)

13.Chandrasegaran, S. K., Ramani, K., Sriram, R. D., Horváth, I., Bernard, A., Harik, R. F., Gao, W.: The evolution, challenges, and future of knowledge representation in product design systems. Computer-aided design 45 (2), pp. 204-228 (2013)

14.Cross, M. S., Sivaloganathan, S.: Specialist knowledge identification, classification, and usage in company-specific new product development processes. Proceedings of the 
Institution of Mechanical Engineers, Part B: Journal of Engineering Manufacture 221 (8), pp. 1285-1298 (2007)

15. Ahmed, S., Wallace, K.: Understanding the knowledge needs of novice designers in the aerospace industry. Design Studies 25 (2), pp. 155-173 (2004)

16. Ahmed, S.: Encouraging reuse of design knowledge: a method to index knowledge. Design Studies 26 (6), pp. 565-592 (2005)

17.Sim, S. K., Duffy, A. H. B.: Towards an ontology of generic engineering design activities. Research in Engineering Design 14 (4), pp. 200-223 (2003)

18.Fruchter, R., Demian, P.: Knowledge management for reuse. Proceedings of CIB w78 Conference, Aarhus School of Architecture, Denmark (2002)

19.Gainsburg, J., Rodriguez-Lluesma, C., Bailey, D. E.: A "knowledge profile" of an engineering occupation: temporal patterns in the use of engineering knowledge. Engineering Studies 2 (3), pp. 197-219 (2010)

20. Joshi, A. W., Sharma, S.: Customer knowledge development: antecedents and impact on new product performance. Journal of Marketing 68 (4), pp. 47-59 (2004)

21. Court, A. W., Culley, S. J., McMahon, C. A.: The influence of information technology in new product development: Observations of an empirical study of the access of engineering design information. International journal of information management 17 (5), pp. 359-375 (1997)

22.Hicks, B. J., Culley, S. J., Allen, R. D., Mullineux, G.: A framework for the requirements of capturing, storing and reusing information and knowledge in engineering design. International journal of information management 22 (4), pp. 263-280 (2002)

23.Hicks, R. C., Dattero, R., Galup, S. D.: The five-tier knowledge management hierarchy. Journal of Knowledge management 10 (1), pp. 19-31 (2006)

24. Baxter, D., Gao, J., Case, K., Harding, J., Young, B., Cochrane, S., Dani, S.: A framework to integrate design knowledge reuse and requirements management in engineering design. Robotics and Computer-Integrated Manufacturing 24 (4), pp. 585-593 (2008)

25. Broens, R. C., Vries, M. J.: Classifying technological knowledge for presentation to mechanical engineering designers. Design Studies 24 (5), pp. 457-471 (2003)

26.Conway, A., Wodehouse, A., Ion, W., Juster, N.: A study of information \& knowledge generated during engineering design meetings. International Conference on Engineering Design (ICED), Paris, 28-31 August (2007)

27. Wodehouse, A.J., Ion, W. J.: Information use in conceptual design: Existing taxonomies and new approaches. International Journal of Design 4 (3), pp. 53-65 (2010)

28. Muller, W., Pasman, G.: Typology and the organization of design knowledge. Design Studies 17 (2), pp. 111-130 (1996)

29. The Free Dictionary, http://www.thefreedictionary.com (visited on 11/04/2016)

30.Zwicky, F.: Entdecken, Erfinden, Forschen im morphologischen Weltbild. München/Zürich: Droemersche Verlagsanstalt Th. Knaur Nachf (1966)

31. Wölfel, C.: How industrial design knowledge differs from engineering design knowledge. International Conference on Engineering and Product Design Education, Barcelona, 4-5 September (2008)

32. Christiaans, H. H. C. M.: Creativity in design: the role of domain knowledge in designing. Doctoral Dissertation, Delft University of Technology (TU Delft) (1992)

33.Demian, P., Fruchter, R.: An ethnographic study of design knowledge reuse in the architecture, engineering, and construction industry. Research in Engineering Design 16 (4), pp. 184-195 (2006)

34.Thor, P., Wenngren, J., Ericson, A.: Knowledge sharing approaches in method development. Proceedings of the 18th International Conference on Engineering Design (ICED 11), Lyngby/Copenhagen, Denmark, 15.-19.08.2011 (2011) 